\title{
Influence of substrate on electricity generation of Shewanella loihica PV-4 in microbial fuel cells
}

\author{
Wenguo $\mathrm{Wu}^{1,2^{*}}$, Fei Yang ${ }^{3}$, Xing Liu ${ }^{2}$ and Linling Bai ${ }^{2}$
}

\begin{abstract}
Background: The substrate, serving as carbon and energy source, is one of the major factors affecting the performance of microbial fuel cells (MFCs). We utilized BIOLOG system to rapidly screen substrates for electricigens, and further evaluated influence of these substrates on electricity generation of Shewanella loihica PV-4 in MFCs.

Results: Three of most favorable substrates (lactate acid, formic acid and cyclodextrin) with $\mathrm{OD}_{590 / 750}$ of 0.952, 0.880 and 0.849 as well as three of most unfavorable substrates (galactose, arabinose and glucose) with $\mathrm{OD}_{590 / 750}$ of $0.248,0.137$ and 0.119 were selected by BIOLOG system under aerobic conditions. The chronoamperometry results showed that MFCs fed with these substrates exhibited different current behaviors. Cyclic voltammograms results showed that arabinose, galactose and glucose promoted electron transfer from outer membrane c-Cyts of cells to the electrode surface. Lactic acid, formic acid and cyclodextrin produced lower quantity of electric charge of 10.13 C, $9.83 \mathrm{C}$ and $10.10 \mathrm{C}$, the corresponding $\mathrm{OD}_{600}$ value was $0.180,0.286$ and 0.152 in BES; while galactose, arabinose and glucose generated higher quantity of electric charge of $12.34 \mathrm{C}, 13.42 \mathrm{C}$ and $17.45 \mathrm{C}$, and increased $\mathrm{OD}_{600}$ values were $0.338,0.558$ and 0.409 in BES. SEMs results showed that plenty of plump and stretched cells as well as appendages were observed when lactic acid, formic acid, and cyclodextrin were utilized as substrates, while sparse cells in short shape were obtained when galactose, arabinose and glucose were used as substrates.

Conclusions: These results suggest that substrate not only has important role in electrochemical performances of MFCs but also in biological properties of electricigens. Lactic acid, formic acid, and cyclodextrin beneficial for cell growth under aerobic conditions are unfavourable for planktonic cell growth and current generation under anaerobic conditions, while consumptions of galactose, arabinose and glucose adverse to cell growth under aerobic conditions are favourable for planktonic cell growth and current generation under anaerobic conditions due to the increase of cell numbers with more outer membrane c-Cyts transferring electrons between the electrode surface and cells.
\end{abstract}

\section{Background}

Microbial fuel cells (MFCs), harvesting electricity from renewable biomass, have attracted great interest in the area of wastewater treatment, bioremediation, biosensors and so on [1-4]. The microbial fuel cell consists of an anode, which accepts electrons released from the microbial metabolism and passes electrons to a cathode, where they are accepted by molecular oxygen. The knowledge that bacteria can generate electric current was first reported by Potter [5]. However, the low power density is

\footnotetext{
* Correspondence: wenguowu@aliyun.com

${ }^{1}$ College of Chemical Engineering, Huaqiao University, 361021 Xiamen, P. R. China

${ }^{2}$ State Key Laboratory of Bioelectronics, Biological science and medical engineering department, Southeast University, 210096 Nanjing, P. R. China Full list of author information is available at the end of the article
}

still one of the main limiting factors restricting the practical application of MFC [6,7]. To overcome this problem, many researchers devote research to the optimization of MFC construction and operation condition [8,9], screening of active electricigens [10], as well as the modification of electrode with nanostructures [11-14]. The substrate serving as carbon and energy source is also considered as a major factor which affects the performance of MFC [15]. However, most of these studies are focused on the limited sorts of single substrate or complex substrates in MFCs with pure culture or activated sludge, respectively.

Shewanella loihica PV-4, a dissimilatory metal reducing bacterium isolated from the Loihi Seamount in Hawaii, has received attention because it generates higher current density than other Shewanella strains [16]. In 
contrast to most Shewanella species, S. loihica PV-4 was able to utilize fumarate, galactose, glucose, citrate, lactate, malate, maltose, $\mathrm{N}$-acetylglucosamine, succinate and alanine as substrates but unable to utilize acetate, propionate or Tween 40 [17]. Although the effect of lactate [16] and a mix of volatile fatty acids [18] as substrates on the performance of MFCs have been evaluated, there is rare report about influence of other single substrates on electricity generation performance and cell growth as well as the interaction between them.

BIOLOG system, taking advantage of microbe's ability to use particular carbon sources to produce a unique "fingerprint" of 95 single carbon sources in a MicroPlate, is widely used for the assessment of bacterial functional diversity in environmental samples [18-20]. The ability of a microbe to use a particular carbon source produces respiration, which reduces a tetrazolium redox dye and causes a color change in that well. The end result is a pattern of colored wells that is characteristic for that organism. Herein, we utilize BIOLOG system to rapidly screen favorable and unfavorable substrates for the growth of S. loihica PV-4, and further evaluate influence of these substrates on electricity generation of S. loihica PV-4 in MFCs.

\section{Results and discussion}

\section{Substrate screening results}

The substrate metabolism process of S. loihica PV-4 was indicated by a tetrazolium redox dye in GN2 MicroPlate. The specific pattern of color change on the plate provided an identifiable metabolic fringerprint. As shown in Figure 1, some wells exhibited noticeable purple color in comparison with the control well (A1) with water as substrate after $25 \mathrm{~h}$ of aerobic culture. Most of negative wells showed no obvious color, it was indicated that the substrates in them are favorable for cellular growth and

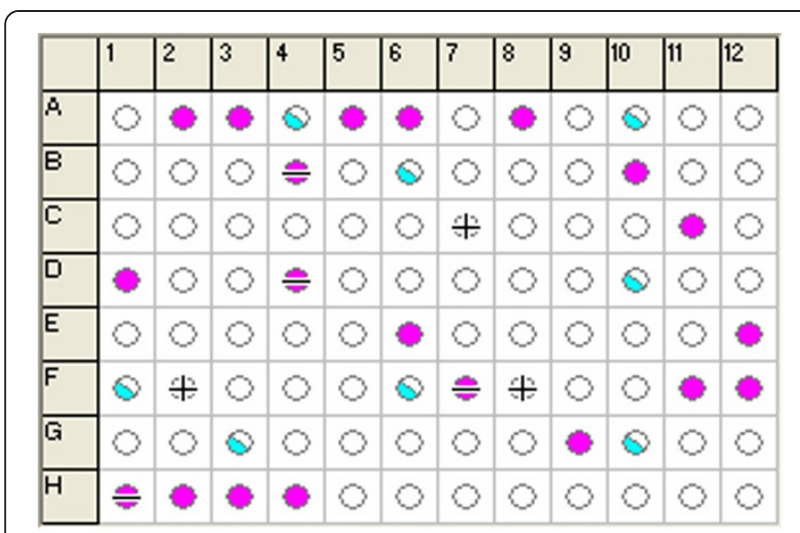

Figure 1 Profiling of S. loihica PV-4 cultures in GN2 MicroPlate using MicroLog software after $25 \mathrm{~h}$ of culture. Purple color: positive, no color: negative, plus and minus: mismatches. respiration. In addition, some wells exhibited half cyan color, it was suggested that the substrates in them are unfavorable. Combined with these $\mathrm{OD}_{590 / 750}$ results, we chose three of the most favorable and unfavorable substrates to study substrate influence on electricity generation of S. loihica PV-4 in MFCs. They were D, L-lactic acid $\left(E 6, \mathrm{OD}_{590 / 750}=0.952\right)$, formic acid (D4, OD $590 / 750=$ 0.880), $\alpha$-cyclodextrin $\left(\mathrm{A} 2, \mathrm{OD}_{590 / 750}=0.849\right)$, D-galactose (B4, $\left.\mathrm{OD}_{590 / 750}=0.248\right)$, L-arabinose $\left(\mathrm{A} 10, \mathrm{OD}_{590 / 750}=\right.$ $0.137)$ and $\alpha$-D-glucose $\left(B 6, \mathrm{OD}_{590 / 750}=0.119\right)$.

\section{Chronoamperometry}

The electricity generation results of S. loihica PV-4 in bioelectrochemical system (BES) at a poised potential of $0.2 \mathrm{~V}$ for $25 \mathrm{~h}$ with lactic acid, formic acid, cyclodextrin, galactose, arabinose and glucose as substrates were shown in Figure 2. With the addition of cells, an oxidative current was generated on ITO electrode, whereas no redox response was observed on the electrode without the addition of cells (data not shown). The oxidative current is ascribed to the electrical connection from outer membrane $c$-Cyts of cells to the electrode [21-24]. As shown in Figure 2, the BES fed with different substrates in the presence of cells exhibited different current behaviors. When formate acid and cyclodextrin were used as substrates, an oxidative current of $0.19 \mu \mathrm{A} \mathrm{cm} \mathrm{cm}^{-2}$ and $0.46 \mu \mathrm{A} \mathrm{cm}$ cm $^{-2}$ was generated, and gradually grew with a broad current peak of $0.71 \mu \mathrm{A} \mathrm{cm} \mathrm{cm}^{-2}$ and $0.57 \mu \mathrm{A} \mathrm{cm}{ }^{-2}$ until $\sim 11.4 \mathrm{~h}$ and $\sim 3.2 \mathrm{~h}$, then decreased slowly to a final current of $0.21 \mu \mathrm{A} \mathrm{cm} \mathrm{cm}^{-2}$ and $0.23 \mu \mathrm{A} \mathrm{cm} \mathrm{cm}^{-2}$ respectively. When lactic acid, galactose, arabinose and glucose were used as substrates, an immediate current

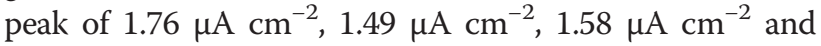
$1.69 \mu \mathrm{A} \mathrm{cm}^{-2}$ was generated and gradually decreased or increased to a final current of $0.30 \mu \mathrm{A} \mathrm{cm}{ }^{-2}, 0.56 \mu \mathrm{A} \mathrm{cm}{ }^{-2}$,

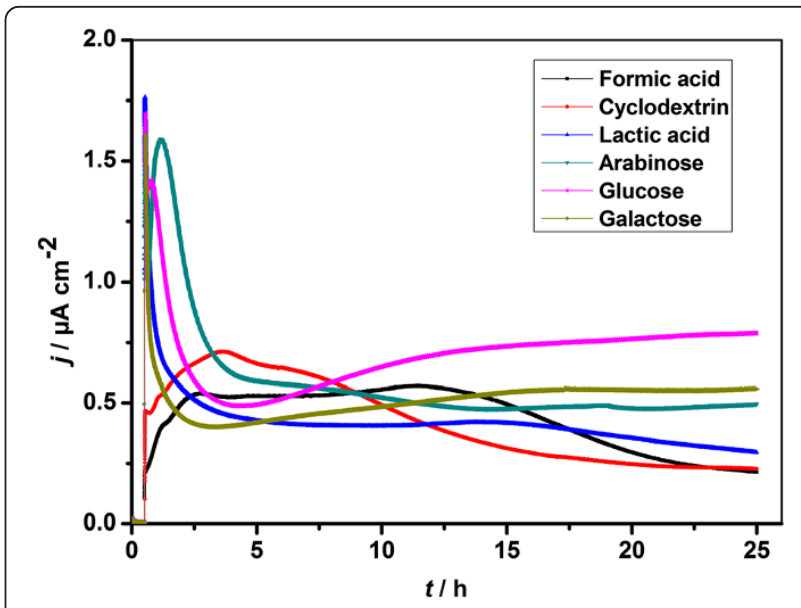

Figure 2 Substrate effect on the electricity generation of S. loihica PV-4 in MFCs. 
$0.50 \mu \mathrm{A} \mathrm{cm} \mathrm{cm}^{-2}$ and $0.79 \mu \mathrm{A} \mathrm{cm} \mathrm{cm}^{-2}$ respectively. Similar chronoamperometry results were observed in the singlechamber, three-electrode electrochemical system with ITO as working electrode and S. loihica PV-4 as electricigens $[22,25]$. However, current was greatly enhanced on graphite $\left(5 \mu \mathrm{A} \mathrm{cm}{ }^{-2}\right)$ [25], nanograss array boron-doped diamond $\left(1.2 \mu \mathrm{A} \mathrm{cm}^{-2}\right)$ [13], and ITO coated with polyaniline nanowire network electrodes $\left(45 \mu \mathrm{A} \mathrm{cm}{ }^{-2}\right)$ [26] due to high surface roughness and nanostructured surface. It was reported that an important aspect of achieving high power density was having a low internal resistance [27]. The total internal resistance consists of anodic, membrane, cathodic, and electrolyte resistance [28]. Among these, anodic resistance is the main limiting factor in internal resistance in this single-chamber, three-electrode electrochemical system where the cathode is platinum wire. The low current generated on ITO electrode was ascribed to increase of anodic resistance from small population of bacteria attached to the plane electrode surface [27]. However, ITO is widely used for spectroelectrochemical characterization of purified redox proteins and whole microbial cells due to its excellent optoelectronics properties [22,25]. Herein, it was chosen for the study of substrate effect on biological and electrochemical properties of S. loihica PV-4.

\section{Cylic voltammetry}

The effect of substrates on electron transfer between S. loihica PV-4 cells and ITO electrode was evaluated by cyclic voltammograms (CVs), after polarizing the electrode for $25 \mathrm{~h}$. As shown in Figure 3, there were no obvious redox waves on ITO electrode in the absence of substrate. After the addition of substrate, pairs of well-defined redox waves were observed on the electrode. The current generation was ascribed to the oxidation of organic compounds

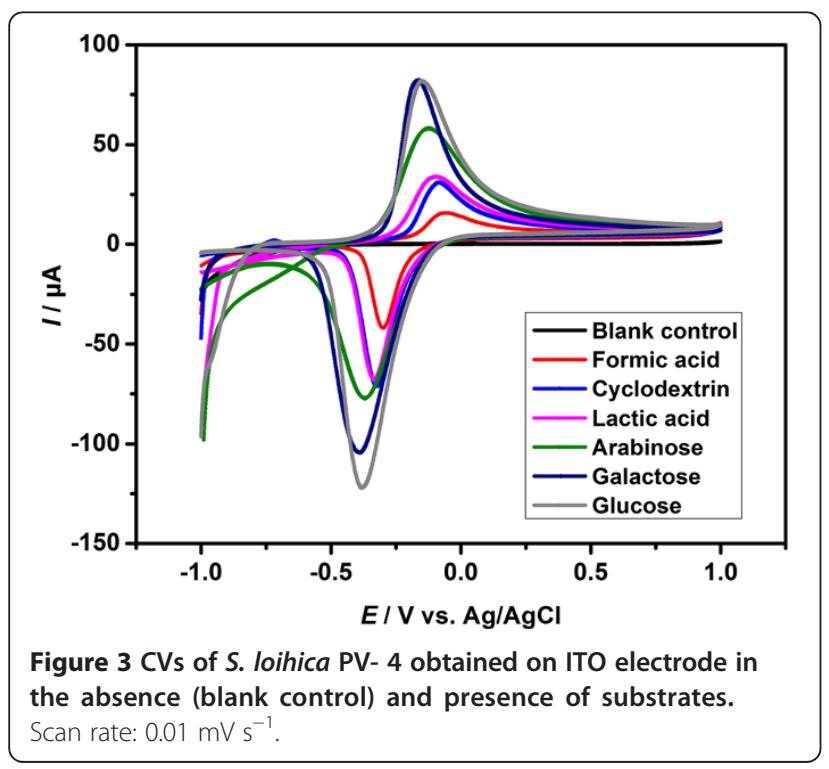

coupled to reduction of electron acceptors by cells. For formic acid, cyclodextrin and lactic acid, CVs showed sharp reductive peaks at $-0.298 \mathrm{~V},-0.318 \mathrm{~V},-0.332 \mathrm{~V}$, and broad oxidative peaks at $-0.060 \mathrm{~V},-0.082 \mathrm{~V},-0.094 \mathrm{~V}$. For arabinose, galactose and glucose, quasi-reversible $\mathrm{CVs}$ with reductive peaks at $-0.336 \mathrm{~V},-0.338 \mathrm{~V},-0.378 \mathrm{~V}$ and oxidative peaks at $-0.124 \mathrm{~V},-0.168 \mathrm{~V},-0.124 \mathrm{~V}$ were exhibited on the electrode. These CVs results confirm an outer membrane $c$-Cyts-mediated electron transfer to the electrode surface $[13,22]$. The cells inoculated in the presence of arabinose, galactose and glucose exhibited higher redox peak currents as compared to those using formic acid, cyclodextrin and lactic acid as substrates. It was indicated that arabinose, galactose and glucose promoted electron transfer from outer membrane $c$-Cyts of cells to the electrode surface and cells fed with these substrates had superior electrochemical performances. These CVs results were in accordance with the chronoamperometry results.

\section{Quantity of electric charge and cell growth}

To further explore the substrate effect on electricity generation, the total quantity of electric charge $(Q)$ was calculated by integrating each $I-T$ curve with respect to time. The formula was $Q=\int_{0}^{t} I d t[29,30]$. The interrelationship between total electric charge and planktonic cell growth under anaerobic conditions with lactic acid, formic acid, cyclodextrin, galactose, arabinose and glucose as substrates in BES after $25 \mathrm{~h}$ was shown in Figure 4. When lactic acid, formic acid and cyclodextrin were used as substrates, the quantity of electric charge of MFC in $25 \mathrm{~h}$ was $10.13 \mathrm{C}, 9.83 \mathrm{C}$ and $10.10 \mathrm{C}$ respectively; the corresponding $\mathrm{OD}_{600}$ value representing planktonic cell growth was $0.180,0.286$ and 0.152 . In comparison, when

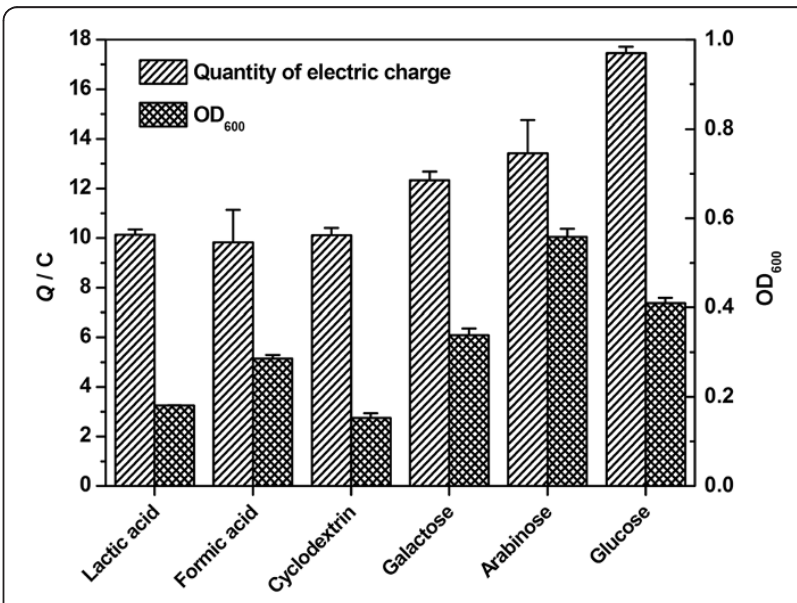

Figure 4 Substrate effect on quality of electric charge and cell growth of S. loihica PV-4 in MFCs after $25 \mathrm{~h}$ of culture. 
galactose, arabinose and glucose were used as substrates, increased quantity of electric charge of $12.34 \mathrm{C}, 13.42 \mathrm{C}$ and $17.45 \mathrm{C}$, and increased $\mathrm{OD}_{600}$ values of $0.338,0.558$ and 0.409 were observed. It was suggested that lactic acid, formic acid and cyclodextrin beneficial for cell growth of S. loihica PV-4 under aerobic conditions were unfavorable for electricity generation and planktonic cell growth under anaerobic conditions, while galactose, arabinose and glucose adverse for cell growth under aerobic conditions were favorable for electricity generation and planktonic cell growth under anaerobic conditions. These results were in accordance with the above CVs results that BES fed with galactose, arabinose and glucose had superior electrochemical performances. This was ascribed to the increase of cell numbers with more outer membrane $c$-Cyts transferring electrons between the electrode surface and cells.

\section{SEM results}

SEM images of S. loihica PV-4 cells on ITO electrode in MFCs after $25 \mathrm{~h}$ of current generation with lactic acid, formic acid, cyclodextrin, galactose, arabinose and glucose as substrates were shown in Figure 5. When lactic acid, formic acid and cyclodextrin were used as substrates, a significant amount of cells in plump and long rod shape were observed on ITO electrodes. Especially when formic acid was utilized as substrate, the length of cells nearly arrived at $\sim 5 \mu \mathrm{m}$ (Figure 5B). Interestingly, when cyclodextrin was used as substrate, there were obvious appendages connecting cells between each other to form a bacterial network. Similar phenomenon was observed when Pelotomaculum thermopropionicum was grown in monocultures on fumarate and in cocultures with Methanothermobacter thernoautotropicus on propionate [31]. These experimental results proved that S. loihica PV-
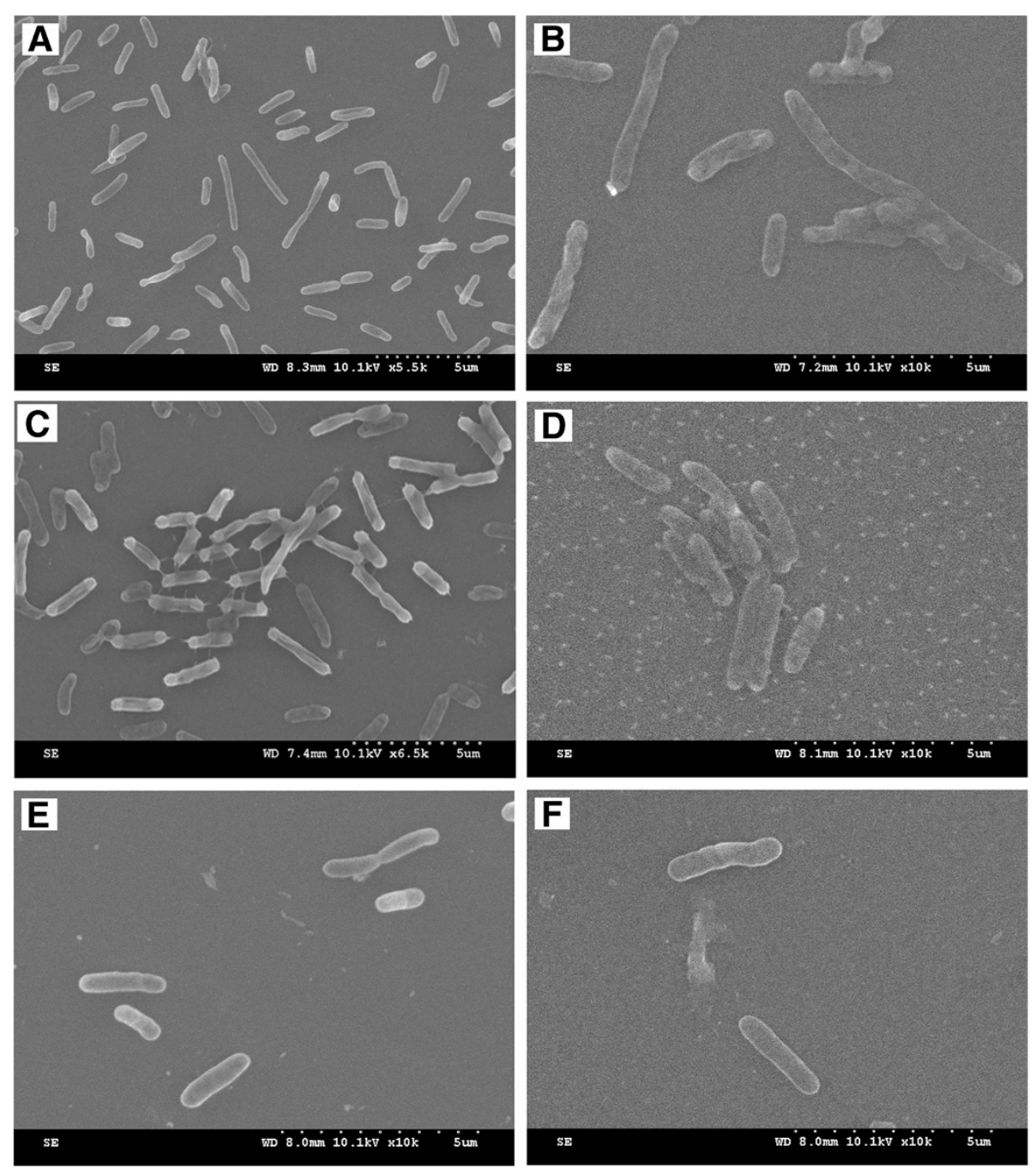

Figure 5 SEM images of S. loihica PV-4 on ITO electrode in MFCs after $25 \mathrm{~h}$ of electricity generation with lactic acid (A), formic acid (B), cyclodextrin (C), galactose (D), arabinose (E) and glucose $(F)$ as substrates. 
4 could also produce pilus-like appendages in response to different substrates fed into MFCs. It was reported that microbial nanowires performed under unnatural conditions [32]. The $\mathrm{OD}_{600}$ value results mentioned above had shown that cyclodextrin was the most unfavourable substrate for planktonic cell growth under anaerobic condition. This unsuitable culture condition could have an important role in the formation of appendages. However, further researches such as the formation mechanism and electrical properties of these appendages are still necessary. When galactose, arabinose and glucose were used as substrates, the cells attached on the electrodes were very sparse and in shorter shape, indicating that the catalytic activity of each individual cell was high. In contrast, bacterial biofilm in uniform morphology was observed on the anode surface of a mixed culture MFC, operated with a high strength wastewater [33]. It was suggested that cellular morphologies together with biological and electrochemical activities of electricigens were significantly affected by substrates.

\section{Conclusions}

Lactic acid, formic acid, cyclodextrin, galactose, arabinose and glucose serving as electron donors for S. loihica PV-4 in MFCs were selected by BIOLOG system. Lactic acid, formic acid and cyclodextrin beneficial for cell growth under aerobic conditions were unfavourable for planktonic cell growth under anaerobic conditions and produced lower quantity of electric charge, while galactose, arabinose and glucose adverse to cell growth were favourable for planktonic cell growth under anaerobic conditions and generated higher quantity of electric charge. The electron donor played an important role not only in electrochemical performances of cells but also in cellular morphologies, especially the formation of appendages. Further researches including underlying formation mechanism and electrical properties of appendages are still necessary.

\section{Methods}

\section{Bacteria culture}

Shewanella loihica PV-4 strain (ATCC BAA-1088) was aerobically cultured in $10 \mathrm{~mL}$ of Marine Broth $\left(20 \mathrm{~g} \mathrm{~L}^{-1}\right)$ at $30^{\circ} \mathrm{C}$ for $24 \mathrm{~h}$. After centrifugation, the Marine Broth was replaced with $10 \mathrm{~mL}$ of defined media (DM) [21] at $30^{\circ} \mathrm{C}$ for $48 \mathrm{~h}$ with different substrates. The suspension was centrifuged for $10 \mathrm{~min}$ and the resultant cell suspension was washed with DM three times prior to being used for electrochemical experiments. As substrates, lactate acid, formic acid, cyclodextrin, galactose, arabinose and glucose $(10 \mathrm{mM})$ were used respectively.

\section{Screening of substrates by BIOLOG system}

S. loihica PV-4 was inoculated and aerobically cultured in Marine Agar $\left(20 \mathrm{~g} \mathrm{~L}^{-1}\right)$ at $30^{\circ} \mathrm{C}$ for $16-24 \mathrm{~h}$. A uniform suspension within the specified turbidity range was prepared by dipping the swab picking up cells into the inoculating fluid. Inoculate cells $(150 \mu \mathrm{l}$ per well) into GN2 MicroPlate (Biolog Catalog \#1011), incubate aerobically at $30^{\circ} \mathrm{C}$ for $25 \mathrm{~h}$ and then read by BIOLOG MicroLog System (Release 4.2, Biolog Inc., USA) with two appropriate filters (590 and $750 \mathrm{~nm}$ ).

\section{Electrochemical measurements}

A single-chamber, three-electrode system was used for the electrochemical measurements, where ITO electrode was used as the working electrode on the bottom of the cell [21], a platinum wire as the counter, and an $\mathrm{Ag} /$ $\mathrm{AgCl}$ (saturated $\mathrm{KCl}$ ) electrode as the reference. The reactor filled with $4 \mathrm{~mL}$ DM containing $10 \mathrm{mM}$ different substrates mentioned above was deaerated by purging with $\mathrm{N}_{2}$ gas (30 min) and subsequently injected with bacterial culture $\left(\mathrm{OD}_{600} 2.0\right)$ as described above at a constant poised potential of $0.2 \mathrm{~V}$ using a $\mathrm{CHI} 660 \mathrm{D}$ potentiostat ( $\mathrm{CH}$ Instruments, Chenhua Co. Shanghai, China) at $25^{\circ} \mathrm{C}$, $\mathrm{pH}$ 7.8. After these electrochemical measurements, the final optical density $\left(\mathrm{OD}_{600}\right)$ of the bacterial culture in the reactor after $25 \mathrm{~h}$ was measured using a spectrophotometer (Mapada, China). All these experimental tests were repeated for one time.

\section{SEM observation}

S. loihica PV-4 attached on the electrodes were imaged using an SEM (HITACHI, S-300 N). Samples were fixed in $2.5 \%$ glutaraldehyde for $2 \mathrm{~h}$, rinsed three times in phosphate buffer ( $\mathrm{pH} 7.0,50 \mathrm{mM})$, dehydrated by alcoholic series $(60,70,80,90,95$, and $100 \%)$, and then airdried.

\section{Competing interests}

The authors declare that they have no competing interests.

\section{Authors' contributions \\ WW carried out the electrochemical measurements, participated in the screening of substrates by BIOLOG system and drafted the manuscript. FY carried out the screening of substrates by BIOLOG system. $\mathrm{XL}$ participated in the electrochemical measurements and SEM observation. LB participated in its design and coordination and helped to draft the manuscript. All authors read and approved the final manuscript.}

\section{Acknowledgements}

This work was supported by National Natural Science Foundation of China (NSFC 81301290), Quanzhou Science and Technology Plan Project (2013Z24) and Research Foundation for High-level Talents of Huaqiao University (12BS207).

\section{Author details}

${ }^{1}$ College of Chemical Engineering, Huaqiao University, 361021 Xiamen, P. R. China. ${ }^{2}$ State Key Laboratory of Bioelectronics, Biological science and medical engineering department, Southeast University, 210096 Nanjing, P. R. China. ${ }^{3}$ Key Laboratory of Environmental Medicine Engineering, Ministry of Education, School of Public Health, Southeast University, 210009 Nanjing, P. R. China.

Received: 23 November 2013 Accepted: 7 May 2014 Published: 16 May 2014 


\section{References}

1. Lovley DR: Bug juice: harvesting electricity with microorganisms. Nat Rev Microbiol 2006, 4:497-508.

2. Wang ZW, Mei XJ, Ma JX, Wu ZC: Recent advances in microbial fuel cells integrated with sludge treatment. Chem Eng Technol 2012, 35:1733-1743.

3. Wang X, Gao N, Zhou Q: Concentration responses of toxicity sensor with Shewanella oneidensis MR-1 growing in bioelectrochemical systems. Biosens Bioelectron 2013, 43:264-267.

4. Pant D, Singh A, Van Bogaert G, Olsen SI, Nigam PS, Diels L, Vanbroekhoven K: Bioelectrochemical systems (BES) for sustainable energy production and product recovery from organic wastes and industrial wastewaters. Rsc Advances 2012, 2:1248-1263.

5. Potter MC: Electrical effects accompanying the decomposition of organic compounds. Proc R Soc Lond B Biol Sci 1911, 84:260-276.

6. Logan BE: Exoelectrogenic bacteria that power microbial fuel cells. Nat Rev Microbiol 2009, 7:375-381.

7. Zhou M, Chi M, Luo J, He H, Jin T: An overview of electrode materials in microbial fuel cells. J Power Sources 2011, 196:4427-4435.

8. Kim BH, Chang IS, Gadd GM: Challenges in microbial fuel cell development and operation. Appl Microbiol Biotechnol 2007, 76:485-494.

9. Osman $\mathrm{MH}$, Shah AA, Walsh FC: Recent progress and continuing challenges in bio-fuel cells. Part II: microbial. Biosens Bioelectron 2010, 26:953-963.

10. Hou HJ, Li L, Cho Y, de Figueiredo P, Han A: Microfabricated microbial fuel cell arrays reveal electrochemically active microbes. PLoS One 2009, 4:e6570.

11. Peng L, You SJ, Wang JY: Carbon nanotubes as electrode modifier promoting direct electron transfer from Shewanella oneidensis. Biosens Bioelectron 2010, 25:1248-1251.

12. Wu WG, Xie RG, Bai LL, Tang ZM, Gu ZZ: Direct electrochemistry of Shewanella loihica PV-4 on gold nanoparticles-modified boron-doped diamond electrodes fabricated by layer-by-layer technique. J Nanosci Nanotechnol 2012, 12:3903-3908.

13. Wu WG, Bai LL, Liu X, Tang ZM, Gu ZZ: Nanograss array boron-doped diamond electrode for enhanced electron transfer from Shewanella loihica PV-4. Electrochem Commun 2011, 13:872-874.

14. Fan YZ, Xu ST, Schaller R, Jiao J, Chaplen F, Liu H: Nanoparticle decorated anodes for enhanced current generation in microbial electrochemical cells. Biosens Bioelectron 2011, 26:1908-1912.

15. Pant $D$, Van Bogaert $G$, Diels $L$, Vanbroekhoven $K$ : A review of the substrates used in microbial fuel cells (MFCs) for sustainable energy production. Bioresour Technol 2010, 101:1533-1543.

16. Newton GJ, Mori S, Nakamura R, Hashimoto K, Watanabe K: Analyses of current-generating mechanisms of Shewanella loihica PV-4 and Shewanella oneidensis MR-1 in microbial fuel cells. Appl Environ Microbiol 2009, 75:7674-7681.

17. Gao HC, Obraztova A, Stewart N, Popa R, Fredrickson JK, Tiedje JM, Nealson $\mathrm{KH}$, Zhou JZ: Shewanella loihica sp nov., isolated from iron-rich microbial mats in the Pacific Ocean. Int J Syst Evol Microbiol 2006, 56:1911-1916.

18. Pant D, Arslan D, Van Bogaert G, Gallego YA, De Wever H, Diels L, Vanbroekhoven $\mathrm{K}$ : Integrated conversion of food waste diluted with sewage into volatile fatty acids through fermentation and electricity through a fuel cell. Environ Technol 2013, 34:1935-1945.

19. Preston-Mafham J, Boddy L, Randerson PF: Analysis of microbial community functional diversity using sole-carbon-source utilisation profiles - a critique. FEMS Microbiol Ecol 2002, 42:1-14.

20. Singh MP: Application of Biolog FF MicroPlate for substrate utilization and metabolite profiling of closely related fungi. J Microbiol Methods 2009, 77:102-108.

21. Smalla K, Wachtendorf U, Heuer H, Liu WT, Forney L: Analysis of BIOLOG GN substrate utilization patterns by microbial communities. Appl Environ Microbiol 1998, 64:1220-1225.

22. Nakamura R, Kai F, Okamoto A, Newton GJ, Hashimoto K: Self-constructed electrically conductive bacterial networks. Angew Chem Int Ed 2009, 48:508-511.

23. Okamoto A, Nakamura R, Ishii K, Hashimoto K: In vivo electrochemistry of c-type cytochrome-mediated electron-transfer with chemical marking. ChemBioChem 2009, 10:2329-2332.

24. Kim BH, Kim HJ, Hyun MS, Park DH: Direct electrode reaction of Fe(III)reducing bacterium, Shewanella putrefaciens. J Microbiol Biotechnology 1999, 9:127-131.
25. Anand J, Jack OC, Richard W, Satheesh K, Enrico M: Extracellular electron transfer mechanism in Shewanella loihica PV- 4 biofilms formed at indium tin oxide and graphite electrodes. Int J Electrochem Sc 2013, 8:1778-179.

26. Zhao Y, Watanabe K, Nakamura R, Mori S, Liu H, Ishii K, Hashimoto K: Three-Dimensional Conductive Nanowire Networks for Maximizing Anode Performance in Microbial Fuel Cells. Chem-Eur J 2010, 16:4982-4985.

27. ElMekawy A, Hegab HM, Dominguez-Benetton X, Pant D: Internal resistance of microfluidic microbial fuel cell: Challenges and potential opportunities. Bioresour Technol 2013, 142:672-682.

28. Torres Cl, Marcus AK, Lee HS, Parameswaran P, Krajmalnik-Brown R, Rittmann BE: A kinetic perspective on extracellular electron transfer by anode-respiring bacteria. FEMS Microbiol Rev 2010, 34:3-17.

29. Bretschger O, Cheung ACM, Mansfeld F, Nealson KH: Comparative microbial fuel cell evaluations of Shewanella spp. Electroanalysis 2010, 22:883-894.

30. Ji JY, Jia YJ, Wu WG, Bai LL, Ge LQ, Gu ZZ: A layer-by-layer self-assembled $\mathrm{Fe}_{2} \mathrm{O}_{3}$ nanorod-based composite multilayer film on ITO anode in microbial fuel cell. Colloids Surf A: Physicochemical and Engineering Aspects 2011, 390:56-61.

31. Gorby YA, Yanina S, McLean JS, Rosso KM, Moyles D, Dohnalkova A, Beveridge TJ, Chang IS, Kim BH, Kim KS, Culley DE, Reed SB, Romine MF, Saffarini DA, Hill EA, Shi L, Elias DA, Kennedy DW, Pinchuk G, Watanabe K, Ishii S, Logan B, Nealson KH, Fredrickson JK: Electrically conductive bacterial nanowires produced by Shewanella oneidensis strain MR-1 and other microorganisms. Proc Natl Acad Sci U S A 2006, 103:11358-11363.

32. Malvankar NS, Vargas M, Nevin KP, Franks AE, Leang C, Kim B-C, Inoue $K$, Mester T, Covalla SF, Johnson JP, Rotello VM, Tuominen MT, Lovley DR: Tunable metallic-like conductivity in microbial nanowire networks. Nat Nanotechnol 2011, 6:573-579.

33. Sevda S, Dominguez-Benetton X, Vanbroekhoven $\mathrm{K}$, De Wever $H_{\text {, }}$ Sreekrishnan TR, Pant D: High strength wastewater treatment accompanied by power generation using air cathode microbial fuel cell. Appl Energy 2013, 105:194-206.

doi:10.1186/1475-2859-13-69

Cite this article as: Wu et al:: Influence of substrate on electricity generation of Shewanella loihica PV-4 in microbial fuel cells. Microbial Cell Factories 2014 13:69.

\section{Submit your next manuscript to BioMed Central and take full advantage of:}

- Convenient online submission

- Thorough peer review

- No space constraints or color figure charges

- Immediate publication on acceptance

- Inclusion in PubMed, CAS, Scopus and Google Scholar

- Research which is freely available for redistribution
C Biomed Central 